\title{
Some obstacles to eliminating famine
}

\section{By N. W. PIRIE, Rothamsted Experimental Station, Harpenden, Herts.}

Few communities can be certain that their food supply is absolutely secure. River valleys show that there are times when a river needs its valley; it may be reasonable to use the valley as farmland if the interval between floods is ro-50 years: it is less reasonable to build houses in it. Similarly, volcanic soil is so fertile that farming the talus slope is profitable between eruptions. These predictable misfortunes are faced as calculated risks: they are brief and the area at risk is limited. The inhabitants can safeguard themselves by maintaining food stores, or by getting help from neighbouring communities. The impact of a plant disease is more varied. The famine caused by potato blight in Ireland had permanent political consequences. The social effects of the disease-enforced change from coffee to tea cultivation in Sri Lanka (then Ceylon) were much smaller. The Bengal famine of 1942 , caused or exacerbated by Helminthosporium devastating the rice crop (Padmanabhan, 1973), had no great effect on the pattern of agriculture. A community that is accustomed to a fairly adequate diet tends to react vigorously and opportunistically to temporary deprivation, it makes use of whatever is edible in the vicinity and, when the crisis is over, it may make changes intended to minimize the risk of recurrence.

In other regions, famine is a continuing threat to people who even in normal times are inadequately fed. This leads to apathy; most of the people are reluctant to make any changes and hardly believe that a better life-style is possible. Such communities are simply catastrophes waiting for a suitable occasion to happen. Most regions in this category suffer from drought. It can be argued that people should not try to live permanently in a region with uncertain rainfall unless it has such resources, e.g. oil, that food can always be imported. Even then, money earned by the resource may not filter down to those in need. Nomadism is a common traditional method for coping with this problem. There are now about I00 million nomads; many of them did not choose this style of life for its own sake but were pushed into inhospitable regions by more vigorous (perhaps because better-fed) neighbours as population pressure increased. Nomads, whether they live in Africa, Australia or the Middle East, have similar life styles; they have small essentially communist communities that neither have nor wish for more property than they can carry (some say, than they can carry in one hand). Nomads cannot be sharply distinguished from 'hunter-gatherers', living in regions with a small and erratic rainfall, who forage over large areas though they may choose to live crowded together when not foraging (Draper, 1973). Though such communities are at risk, various surveys (e.g. Harris, 1962; Truswell, Hansen, Wannenberg \& Sellmeyer, 1969; Bhandari, 1974; Calloway, Giauque \& Costa, 1974; Newman, 
1975) show that their diet is meagre but good, and better than that supplied by food bought or donated by welfare projects. Until the culture of these people is more fully understood, and until it is certain that a change would be an improvement, interference would be unwise.

The position is different in settled areas threatened by drought. The immediate impulse is to introduce water. There is now a welcome swing of opinion away from enormous dams and towards many small dams nearer the headwaters of rivers. Underground water is more abundant than surface water: an obstacle to its fuller exploitation is the assumption that the only alternatives to human or animal power for raising it are electric motors or internal combustion engines. Windmills are considered old-fashioned and solar engines futuristic. A bonus from the 'energy crisis' is that technically competent countries will undertake serious research on alternative prime-movers. Desert areas are often windy and always sunny.

Plants vary greatly in the extent to which they transpire. Maize needs less water to produce a ton of grain than wheat does; sorghum and millet need less than maize: but prestige is not proportionate to water economy. Fortunately, there is now great interest in the physiological differences between $\mathrm{C}_{3}$ and $\mathrm{C}_{4}$ plants (so-called because of the appearance of either triose phosphate or a $\mathrm{C}_{4}$ acid as the most easily identified early product of photosynthesis) because of the greater efficiency with which the latter use strong light, especially when the plants are young. $\mathrm{C}_{4}$ plants also use water more efficiently; this may be a more important merit because it persists in the mature plant. Maize, millet and sorghum are $\mathrm{C}_{4}$ plants, and so are a few green vegetables. To make life less hazardous in arid areas, much more research on $\mathrm{C}_{4}$ plants is needed. Looking further into the future we may consider some plants that give very large yields of organic matter in hot environments with intense sunlight (Bjorkman, Pearcy, Harrison \& Mooney, 1972). Those studied 80 far do not produce anything that is useful as food or fodder. An obstacle to the elimination of famine is inadequate awareness that there is an exploitable potentiality here. Besides producing fodder, an extension of the amount of plant cover on a desert could ultimately diminish the amount of desert. Charney, Stone \& Quirk (1975) point out that the albedo of herbage is 10-25\% whereas that of sandy soil is $\mathbf{3 5 - 4 5 \%}$; they suggest that surfaces absorbing more radiant energy should get greater cloud cover and rain.

From the time of Plato it has been clear that deforestation and overgrazing were a cause of aridity. Even where rainfall is adequate, there is an optimal number of grazing animals for an area. Consequently, if a few more are introduced, the yield diminishes steadily. This was well known in medieval times: commoners had the right to graze a prescribed number of animals and no more. If collective agreement made this possible in Britain 600 years ago, there is no obvious reason why it should not be possible in Africa and India today. There is no advantage in irrigating land, and planting improved forage on it, if every green shoot is eaten before it has time to photosynthesize. There are many obstacles to adequate control. People are proud of cattle, and in many communities they are the principle currency. At one time this was probably the position in Britain: the Old English and Shakespearian word 'neat' is derived from 'neotan', which meant to possess. 
Inflation has hit this currency as it has hit others: in Kenya a wife costs four times as many cattle as she cost 40 years ago (Goldschmidt, 1973). Cattle are a convenient short-term store; they can be fattened when forage is abundant, and eaten later when privation or famine is imminent. With a crop, there is a correct time for harvest, and drought may precede it. In some present-day African communities, as in Scotland and Ireland in the past, cattle are regularly 'tapped' for blood. But they have no peculiar merits for any of these purposes and it is hard to see why they have such a pre-eminent position.

There is much unused land in humid regions on which cattle could be raised (McMeekan, 1969); it might be possible to persuade some of the inhabitants of famine-prone regions to migrate. Various proposals to increase the cattle-carrying capacity of semi-arid regions should be looked on less favourably because cattle, probably because of their lung and kidney structure, use more water than many other large herbivores. Herders are often distressed by the sleek appearance of wild animals such as zebra and eland when their cattle have become emaciated. Furthermore, different species prefer different types of forage (Gwynne \& Bell, 1968) so that a mixture of animal species should, in principle, be more efficient than a single species. These points have been fully discussed, and species suited to different parts of the world are suggested by others, e.g. Jewell (1968), Kay (1970) and Blaxter (1975). Goats have often been condemned as destroyers although they can flourish on forage rejected by cattle in the early stages of a famine. Fortunately, their merits are being recognized (Devendra \& Burns, 1970; Devendra, 1974). Like other species, they become a pest when too numerous.

Regions threatened with famine because of intermittent flooding face entirely different problems and have fewer options. Various forms of flood control are well understood and, so far as the technical capacities of the countries permit, used. The only possible food source that is underexploited in a flood is the mass of water weeds and other forms of floating vegetation. A little attention is now being paid to its use as cattle fodder (Little, 1970; Soewardi, 1974), but once there is a flood it is too late to start feeding cattle. Although edible protein can be extracted from many species of water weed (Boyd, 1971; Matai, 1973; Pirie, 1975), little use is being made of this potentiality. The obstacle here is the almost universal assumption that water weeds are a pest to be destroyed rather than a resource to be used. An 'expert' at a recent seminar on noxious aquatic vegetation announced flatly that work had not 'produced a product that can compete in the market place with similar products from other sources'. Historically this may be true; it should not be assumed that the position is unalterable. Less effort has been put into finding uses for a weed such as water hyacinth than a large commercial concern would put into redesigning a food package.

The main obstacle preventing these and other possibilities from at least minimizing the effects of famine is that the basic research has not been done. It is salutary to remember that some early settlements in several regions now embarrassed by food surpluses, e.g. parts of Australia and the USA, had to be abandoned because of famine. Farming skill adapted to the local conditions came later. Several years of conscientious research in famine-prone localities are likely to 
be needed before improved methods are worked out. That sounds obvious, but 'experts' have too often barged in with advice, seemingly unaware that you cannot teach what you do not know. It is as useless to try to solve a novel and local problem with alien technology as it is to try to solve it with food shipments.

The return from agricultural research is so large that, purely for financial reasons, more money should be spent on it. Unfortunately, what is spent mainly benefits countries not faced with famine, and what is spent in countries faced with famine benefits mainly the wealthier farmers there (FAO, 1974; Griffin, 1974). The Food and Agriculture Organization (FAO) committee (FAO, 1974) stressed the importance of research on problems arising in arid lands, and pointed out that their population will be 400 million by the end of the decade. It also stressed the value of research on 'intermediate technology' projects that would benefit small farmers: but it did not suggest how this research should be financed. The foundations and international agencies are the only likely source of finance because industry would gain little from work benefiting those who have little or no money. The outlook, however, is not altogether gloomy. FAO (e.g. FAO, 1968) has for many years stressed the importance of practical as opposed to academic research, but its outlook has been market-orientated. This was clearly stated (FAO, 1969): '... FAO has not thought in terms of theoretically desirable nutritional standards. Instead the Indicative World Plan is concerned primarily with projecting the effective economic demand for food'. As Aykroyd (1974) has eloquently explained, you cannot combat famine while abiding by the principles of political economy. Need has recently had more attention. Billaz (1974), writing in the FAO journal Ceres, called for 'organic liaison between peasantries and research establishments'. Papers written mainly by FAO as a prelude to the World Food Conference (UN Economic and Social Council, 1974) called for reorientation of agricultural technology towards the problems of small farmers and hot countries, and stressed '. . fundametal right of each individual to have adequate food and nutrition', and welcomed attempts at social improvement in rural areas. The idea has spread to the International Bank for Reconstruction and Development: in 1964-8, countries with a gross national product (GNP) of $\$ 376-700$ /person per year got $40 \%$ of agricultural loan money, and countries with a GNP $<\$ 150 /$ person per year got $24.5 \%$; the figures were reversed in 1969-73 (Donaldson \& Bates, 1974). The International Monetary Fund and World Bank now see that projects should be favoured according to their probable benefit to the poorest section of a community (Adler, 1973) and that small farms may get better yields than large (McNamara, 1973). The assertion that the best way to improve conditions in a country is to push it up from the bottom, rather than pull it up from the top, used to be stigmatized as visionary: it has become orthodox.

Having found a better crop, animal, or technique, getting it into general use is the next obstacle. In affluent countries there is one agricultural agent for about 400 rural families, in developing countries there is one for 8000 (McNamara, 1973). More extension officers are obviously needed, and more of them should be women in regions where most farm work is done by women. But example is much more effective than instruction, as Mann argued $5^{\circ}$ years ago (Thorner, 1967 ). Many 
farmers, each persuaded to take a mild interest in an innovation, are much less effective than a single farmer fully convinced. If the innovation works on one ordinary farm it will be copied by the neighbours. Copying was an important factor in the spread of hybrid maize in the USA (Sprague, 1970), various marketgardening techniques in Trinidad (MacMillan \& Edwards, 1970), and various agricultural improvements brought about by the Shell company in Italy and elsewhere (Cox, I966). Change is greatly facilitated if the government or some other agency insures a farmer against loss should an innovation fail for any reason (FAO, 1974).

There are so many real obstacles to the elimination of famine that the parading of pseudo-obstacles is irritating. Any of the changes suggested here will involve some change in food habits. We are often told that these are nearly immutable. On the contrary, they change inconveniently easily, so that traditional foods may become unfashionable before the desired alternatives can be produced locally. Berg (1972) and Pirie (1972) quote many examples of changes in eating habits, usually detrimental. The adoption of cassava, chillies, groundnuts, maize, pumpkins and tomatoes by African peasant farmers, of their own volition, is more commendable. Bureaucrats are the main obstacle to change; in my experience, a senior civil servant is the only person to have made the fatuous comment 'I prefer beefsteak' on being given a dish containing leaf protein. Prawl (1969) analysed this attitude in an article called 'It's the agents of change who don't like change', and it has been labelled the 'Todhunter Principle' after a civil servant in India many years ago who said that all notes added to a file should show that the proposal in it would not work. The 'Cornford Principle' is similar: 'Nothing should ever be done for the first time'.

Indubitably political changes and changes in styles of land ownership in famineprone parts of the world would do much to prevent or mitigate famine. In these ways the 'cake' would be more equitably divided. It is of equal immediate importance, and of greater long-range importance, to devise agricultural techniques that will increase the size of the 'cake'.

\section{REFERENCES}

Adler, J. H. (1973). Finan. Dev. 10, 2.

Aykroyd, W. W. (r974). The Conquest of Famine. London: Chatto \& Windus.

Berg, A. (1972). Harv. Business Rev. p. 130.

Bhandari, M. M. (1974). Econ. Bot. 28, 73 .

Billaz, R. (1974). Ceres 7,34 .

Bjorkman, O., Pearcy, R. W., Harrison, A. T. \& Mooney, H. (1972). Science, N.Y. 175, 786. Blaxter, K. L. (1975). In Food Protein Sources, p. 147 [N. W. Pirie, editor]. London: Cambridge University Press.

Boyd, C. E. (1971). In Leaf Protein: its Agronomy, Preparation, Quality and Use, p. 44 [N. W. Pirie, editor]. Oxford: Blackwell Scientific Publications.

Calloway, D. H., Giauque, R. D. \& Costa, F. M. (1974). Ecol. Fd Nutr. 3, 203.

Charney, J., Stone, P. H. \& Quirk, W. J. (1975). Science, N.Y. 187, 434.

Cox, I. H. (1966). The Transformation of Rural Communities: The World Land Use Survey, no. 7. Berkhamsted, Herts: Geographical Publications Ltd.

Devendra, C. (1974). Span 17, 130.

Devendra, C. \& Burns, M. (1970). Tech. Commun. Commonw. Bur. Anim. Breed. Genet. no. 19.

Donaldson, G. F. \& Bates, D. J. (1974). Span $17,98$. 
Draper, P. (1973). Science, N.Y. 182, 301.

FAO (1968). The State of Food and Agriculture. Rome: FAO.

FAO (1969). Provisional Indicative World Plan for Agricultural Development. Rome: FAO.

FAO (1974). Report of the Second Session of the Committee on Agriculture. Rome: FAO.

Griffin, K. (1974). The Political Economy of Agrarian Change. London: MacMillan.

Goldschmidt, W. (1973). Scient. Am. 229, 74.

Gwynne, M. D. \& Bell, R. H. V. (1968). Nature, Lond. 220, 390.

Harris, R. S. (1962). Archs Envir. Hlth 5, 144.

Jewell, P. A. (1968). Nature, Lond. 218, 993.

Kay, R. N. B. (1970). Proc. Nutr. Soc. 29, 271.

Little, E. C. S. (1970). Pestic. Abstr. B 16, 198.

McMeekan, C. P. (1969). F. biosoc. Sci. 1, 405.

MacMillan, A. A. \& Edwards, D. T. (1970). In Change in Agriculture, p. 181 [A. H. Bunting, editor]. London: Duckworth.

McNamara, R. S. (1973). Ceres 7, 19.

Matai, S. (1973). Noxious Aquatic Vegetation in Tropics and Sub-tropics, p. 58. New Delhi: Indian Natural Sciences Academy and UNESCO.

Newman, J. L. (1975). Ecol. Fd Nutr. 4, 33.

Padmanabhan S. Y. (1973). A. Rev. Pl. Path. II, II.

Pirie, N. W. (1972). Ecol. Fd Nutr. 1, 279.

Pirie, N. W. (1975). In International Symposium on Food from Waste. Barking, Essex: Applied Science Publishers.

Prawl, W. L. (1969). Ceres 2, 57.

Soewardi, D. (1974). South-east Asian Workshop on Aquatic Weeds, Malang, fava.

Sprague, G. F. (1970). In Change in Agriculture, p. 90 [A. H. Bunting, editor]. London: Duckworth.

Thorner, D. (editor) (1967). H. H. Mann: The Social Framework of Agriculture: India, Middle East, England. Bombay: Vora \& Co.

Truswell, A. S., Hansen, J. D. L., Wannenberg, P. \& Sellmeyer, E. (1969). S. Afr. Med. \}. 43, II 57:

UN Economic and Social Council (1974). World Food Conference: Provisional Agenda, items 8 and 9. Rome: UN Economic and Social Council. 